\title{
Online Teaching of Languages: A case study of Moi University, Kenya.
}

\section{Seminega Corneille Emmanuel \\ Michael Gichangi Nginye}

\begin{abstract}
Online learning is the fastest growing trend in education. It has fundamentally changed the way people learn, communicate and do business. Its adoption at various levels of education can greatly transform the nature of education including "where" and "how" education takes place and the roles of students and the teachers in the learning process. Therefore information and Communication Technology (ICT) is a powerful tool for extending education opportunities, to previously disadvantaged areas which include: scattered rural populations traditionally excluded from education due to cultural or social reasons such as ethnic minorities and gender. The use of computers (or even mobile phones) as tutors for drill and practice and instructional delivery combined with traditional instruction can result in increased learning which will be evidenced in students learning more quickly, demonstrating greater retention and being better motivated to learn. The objective of this study is twofold: To find out the benefits of ICT in teaching of languages and also whether the teaching of languages online faces particular challenges as compared to other subjects, the study case being Moi University.
\end{abstract}

Key words e-learning; m-learning; Drill 


\section{Introduction}

Time, distance and languages have always been hurdles for the formal education system. After the emergence of Information Technology, the technological solutions like developments in information, communication and computing technologies have made available powerful tools to a large sector of the population. Video Conferencing, Satellite Applications, INTERNET and World Wide Web (WWW) started changing the life styles of modern population. In education system also, an environment in which, learning is facilitated by multidimensional, at one axis the content producer/deliverer and on the other end a learner with the help of software applications for teaching and learning, has emerged. Obviously, these useful tools, which avoid several barriers, lead to setting-up of digital/virtual/e-campuses or e-varsities for E-learning. Global connectivity must mean more than technology and commerce; it must lead to global learning, and the inculcation of values that set apart a civilized human being (Menon, 2001). The recent advances in technology have necessitated first, new approaches and then new methodologies in the area of foreign language learning and thorough teaching. The Internet and the virtual learning environments have diversified the opportunities for school tutors, instructional designers as well as learners by varying and broadening the alternatives for learning and teaching of languages (Menon, 2001).

In this regard, online learning is the fastest growing trend in education. For instance, there are over one million online learners in the United States of America and this trend is constantly growing with 65\% growth rate between 2002 and 2005 (Kesley, 2009). This is supported by the Government of Kenya (GoK) (2010) which asserts that the use of information and communication technologies (ICT) in learning is a major catalyst shaping the global economy with the potential of producing the desired goals. It has fundamentally changed the way people learn, communicate and do business. It has further spurred increased creativity, innovation, high values and the entrepreneurial spirit. As a result, its adoption at various levels can greatly transform the nature of education including "where" and "how" it takes place and the roles of students and teachers in the learning process. In spite of this, the use of Information and Communication Technologies in education is a relatively new phenomenon in Kenya. Though, GoK (2010) reveals that Kenya through the Ministry of Education is committed to the integration of ICT in education in order to ensure the provision of quality education and training to all learners. 


\section{E-learning and E-learning system.}

This is a system of learning that allows our learners, scholars, researchers and the greater public to learn, to search, to research and to acquire essential knowledge using the benefits of highspeed network connections, Internet, and all this without any time, distance and community constraints. Online learning programs that take advantage of high-speed cable connections allow everyone to learn and acquire essential knowledge at times that do not interfere with their work or personal schedules. Online education has changed the essence from Teaching to learning. It stretches its wings from campus or classroom to home or work place or the entire community. Here, educational reaches are global and wide. The idea of single institution changes to consortia approach, where all of them are networked together by electronic network. Students also changed from traditional to techno-savvy; many of them grew up with computers in their homes, or libraries or schools and view a computer as a tool rather than the mystical blue or black box (Butler, 2000).

Thus, it can be argued that online learning encompasses the use of an information network for instance, the internet, an intranet (LAN) or extranet (WAN) whether wholly or in part for course delivery, interactions and facilitations. It uses gadgets such as videos, television, and multimedia computer software that combine text, sound, colour and moving images to not only increase learner's motivation but also engage the learner more in the learning process. In practice, through drill and practice of Information and Communication Technologies (ICTs) the transmission of basic skills and concepts that are the foundation of higher order of thinking and creativity are facilitated (GoK, 2010).

According to Kelsey (2009), online learning can be defined as presenting instruction using the internet as the primary form of delivery. In other words, it refers to integrating Information and Communication Technologies (ICT) in education. In essence, e-learning entails: presentation, demonstration and manipulation of data using productivity toll and usage of educational curriculum-specific application types which include educational games, drill, practice, simulations, tutorials, virtual laboratories, visualization, graphical representation of abstract concepts, musical composition and expert systems. It also involves the usage of information and resources of $\mathrm{CD}$ Rom or online encyclopedias, interactive maps, atlases, electronic journals among other references. 
Kelsey (2009) asserts that online learning can take two formats: Synchronous and Asynchronous. Synchronous refers to situations where the instruction is delivered and received in real time with examples being satellite, Skype, VOIP and live chat. Asynchronous on the other hand is when the instruction is delivered and received at different times with an example being CMS (Content Management System) which incorporates e-mail, text, and recorded lectures. Content Management System, in particular, allows the teacher to present content to students.

\section{Usage of Information and Communication Technologies as Online Learning Tools}

According to GoK, 2010, Information and Communication Technology (ICT) is a potentially powerful tool for extending education opportunities, both formal and informal to previously disadvantaged areas. This may include not only scattered rural populations traditionally excluded from education due to cultural or social reasons such as ethnic minorities, girls and women, persons with disabilities, the elderly, but also persons who for reasons of cost and time constraints are unable to access education opportunities available to others. Thus, a majority of online learners range from busy, task-oriented, goal-focused, motivated and self-directed working professionals who are not only time and place bound but also intellectually stimulated to recreational people and retirees (Kelsey, 2009).

Information and Communication Technology has the potential of enhancing the quality of education in several ways by increasing not only learner motivation and engagement, but also, facilitating the acquisition of basic skills and by enhancing teacher training. GoK (2010), asserts that ICTs (Information and Communication Technologies) are transformational tools which, when used appropriately, can promote the shift to learner-centered environment.

\section{E-learning in Kenya}

The government of Kenya is committed to the integration of ICT in education, in order, to ensure that there is provision of quality education and training to all learners. The use of ICT in education and training has the capacity of overcoming challenges of time and location leading to flexible and life long learning. The proper and well-planned use of new technology will no doubt be of great benefit to Kenyans. GOK (op. cit) asserts that the Kenyan government wants education and training professionals to embrace ICT in curriculum development and delivery. The Kenyan government is committed to achieving education for all (EFA) goals and the vision 2030. Education through ICT will go a long way in making this a reality since this will enhance 
quality, equity and access to education. The technology based education is government-driven to ensure that all Kenyans access education. In the recent years the Kenya government's priority has been to increase access, equity and relevance in quality education (GoK, 2010). It embraces the notion of alternative teaching and learning opportunities and recognizes the fact that the use of technology can provide opportunities to learner-centered teaching, enhanced access, greater teacher-to-teacher and student-to-student communication and collaboration. It also ensures greater enthusiasm for learning amongst students. With the provision of a dedicated digital educational channel, learners will be able to access audio, video and multimedia content. The power of digital learning will play a central role in enhancing the learners' acquisition of marketable skills necessary for operating effectively in a highly competitive world of the $21^{\text {st }}$ century which requires learners to have the requisite competencies to be productive in a knowledge-based economy. Access and technology-driven policies and practices increase capacity building among teachers, students and in particular the integration of ICTs into the instructional processes and content development. For example, schools will be able to teach science subject such as chemistry or biology, with laboratory experiments animated via learner participatory mode with minimum recurrent costs.

\section{Ministry of Education}

The development of the digital content is a major flagship of the ministry of education ICT strategy, which aims at harnessing access to technology-driven practices. The ministry has set up a ministerial ICT integration team to facilitate and main-stream the provision and management of hardware and software requirements in education using an integrated approach.

The ministry of education in collaboration with stakeholders will continue to equip schools and regional administrative education offices with computers and build the capacity of human resource to deliver their functions effectively by use of ICT. GoK (2010), reveals that the journey on uptake of ICT usage in education has just started and the tasks ahead still require concerted efforts from all stakeholders and especially partners in the public and private sectors. In spite of this, there are a number of challenges facing e-learning. These are: inadequate infrastructure at levels of education, prohibitive cost of installing and maintaining the necessary equipment, capacity building for curriculum developers and teachers and the highly challenging process of developing the e-content. GOK (op. cit.) affirms that as part of the strategy to meet the above challenges, Kenya Institute of Education (KIE) has developed an online course for orientation of primary school teachers on curriculum interpretation and 
implementation. This will enable the ministry of education to empower teachers on curriculum delivery.

The following critical issues are necessary for the delivery of quality education through elearning and must be addressed urgently in order to fulfill desired aspirations: digital content, capacity building, infrastructure, and overall ICT integration in education. The e-content for schools is expected to aid the learning process by harnessing the benefits associated with digitized content including animation, simulation and graphical illustrations. The digitization of content will also facilitate virtual learning and enable access to the education content by any learner in the country who has access to ICT facilities. Digital content has the potential to revolutionize teaching and learning in Kenya. 


\section{KIE as a model in the use of ICTs in Kenya}

The Kenya Institute of Education (KIE) is in the front line of promoting quality education through production of quality curriculum and curriculum support material. Its functions include the provision and delivery of instructional and educational materials via all electronic media including the internet, intranets, extranets, satellite, DVDs, CD ROMs, interactive internet, radio, television, mass media and video among others.

KIE started e-learning in 2005. During the two first years, the institution went through capacity building. From 2008 up to now, KIE has managed to develop teaching materials for primary school and secondary school.

The ministry of education through KIE has embarked on three approaches in the development and delivery of e-content. These approaches; are the development of digital content in twelve (12) form one and twelve(12) form two subjects for secondary school level, the development of digital content for primary mathematics and science for standard four (4) and five(5), and KIE Elimika ${ }^{1}$ Learning Management System (LMS) which is a Kenyan digitization platform. This is as a result of the collaboration of the 13 African universities involved in the African Virtual Open Initiatives and Resources (AVOIR) project. It is a by-product of the Chisimba ${ }^{2}$ initiative whose aim is to explore alternative ways of developing content using the most cost effective way. Elimika which has been customized by KIE as a Kenyan Learning Management System aims at fostering capacity building in software engineering among African universities through the collaborative development of free software. The platform allows development of content within it and also importation of content authored in other software into Elimika for processing and dissemination. Through the use of this platform, the Institute has developed online modules for orientation of teachers to assist them understand and interpret the syllabus content more effectively. The modules cover several subjects taught in the primary school curriculum. For primary school, KIE has managed to finish developing contents for mathematics and sciences for class 3 and 4; in addition, it has developed 12 subjects for form 3 and 4, taken by most of the students in secondary school while content for Form 1 and 2 will be developed later. The Institute is in the process of developing online content to orientate secondary school teachers on the curriculum.

\footnotetext{
${ }^{1}$ Elimika is a KIE learning management system based on chisimba. Elimika system is based in the US but an administrator of e-learning is based at KIE.

${ }^{2}$ Chisimba is a Web 2.0 enabled rapid application development framework for creating web applications that are platform independent, browser independent, XHTML compliant, and can use a number of common databases.
} 
Despite these milestones, the Institute faces various challenges with regard to the development of e-content. These include: High turnover of trained, skilled and competent staff (this affects the content development, content delivery and teacher training in utilization of the content), poor internet connectivity due to insufficient bandwidth, lack of adequate infrastructure within the Institute and in most of the learning institutions including primary and secondary schools and also teacher training colleges, lack of basic computer literacy skills among the users thus slowing down the implementation process and fear of technology by the users especially because they lack the necessary skills.

\section{E-Learning at Moi University: DODL (Directorate of Open and Distance Learning)}

\section{Background Information}

In Kenya, institutions of higher education mandated to offer high quality education leave out annually over 30000 qualified Kenyans who seek University admission. More to the point, there is increasing demand from individuals in employment who want to obtain higher qualifications yet they cannot easily get access the programmes of their choice. This is so, because the universities continue operating on limited physical infrastructure (lecture space, laboratories, office space) and rely entirely on the face-to-face lecture methods that cannot allow a large number of students to be taught synchronously (in real time by same lecturers). The Kenyan Government is cognizant of the acute demand for university education and its inability to address this challenge by using the conventional delivery mode of education that is, face-to-face lecturer/student interaction practiced by the universities. Thus, in Sessional paper No.1 of 2005, the Government emphasized that one of the major ways of expanding access and equity of university education is through Open and Distance Learning (ODL), a form of education provision designed to facilitate learning where the teacher and learner are physically separated, thus requiring a mediated environment. Following this, the Ministry of Higher Education, Science and Technology is developing strategies intended to spearhead the establishment of a National University of Kenya offering programmes through Open and distance learning modes, while at the same time enhancing already existing programmes.

Open and Distance Learning is now fast becoming the preferred mode of study as it has several advantages including flexibility in choice of programmes and courses especially with regard to what, where and when to take them. It provides an opportunity for students in the (face-to-face) 
programmes to use this mode to accelerate completion of their study, therefore, maximizing the utilization of time while at the University. In addition, a learner can study while undertaking other responsibilities (for example employment and social responsibilities) at the same time.

Open and Distance Learning (ODL) has several advantages which include, flexibility in choice of programmes/courses (what, where and when to take them), and is not limited by physical capacities education). An individual can learn and undertake other responsibilities at the same time (employment, social). In addition, issues associated with conventional mode of education provision such as students' strikes, inadequate accommodation, limited lecture and office space and high costs of medical care are not the concern of the University. It also enables students to take courses they can afford at any given time. Open and Distance Learning (ODL) enables economies of scale in education provision in that materials prepared by one expert can be used by thousands of students. Finally, it makes use of technologies of the day and therefore provides an opportunity to access education for those who, for various reasons, cannot attend residential programmes.

Since its establishment in 1984, Moi University has remained largely a single mode institution. However, with advancements in information and communication technology and their impact on education, there are many changes which continue to emerge.

It is in recognition of these advantages and the potentials of Distance learning that Moi University has put Open and Distance Learning as one of the planned activities in its strategic plan. Moreover, the Directorate of Distance Learning (DODL) was established at Moi University in November, 2007. The directorate is currently located in the Administration block of RIVATEX East Africa LTD, a Moi University Facility in Eldoret town. It has a computer laboratory based at Kiptagich house, in the same town of Eldoret. The computer laboratory is used for training staff and for teaching purposes.

The Directorate is mandated to co-ordinate all ODL programmes of the University. Issues of access, flexibility, quality and equity in education continue to be the concern of those charged with the management of education. Open and Distance Learning (ODL) which is a flexible mode of education, will provide alternative opportunities for further education thus expanding access to Moi University academic programmes. It is also expected that ODL will enhance the quality of academic programmes and at the same time enhance the quality of academic programmes (DODL, 2008). 
The Directorate is specifically designed to address issues pertaining to open and distance learning within the University. Attitude towards a new development can break or make its implementation. The following issues need to be addressed: adoption of innovations, acceptance of e-learning/on-line/distance teaching and understanding of distance education (what works at a distance), or organizational values. These problems are addressed gradually through appropriate training, workshops and conferences targeting all staff and prospective students (DODL, 2008).

The Directorate serves as a link between students and their various schools of Moi University. It offers expertise and equipment, while the schools offer the content. It intends to use various campuses of Moi University catered around the country to establish more centres of E-learning. Content is delivered to the Directorate in the form of modules which are loaded to DODL platform on the Moi university website. The learning management system used by DODL is the same by Kenya Institute of Education. Content of any given course is only accessible to the administrator of the platform, the lecturer who loaded it and the authorized students. Continuous Assessment Tests (CATs) and exams can be given through the web and access denied to students after a given specific time. Students are able to share and exchange comments with colleagues or ask questions to the lecturer. All together the lecturer is able to monitor who logs in and the time spent online.

The Directorate has organized many training sessions for academic and senior administrative staff on how to use the platform especially how to load content on it and copyright of the developers of the modules.

DODL is targeting workers who want to register in different postgraduate programs and undergraduate school based programs offered by Moi University.

The success of E-learning which is yet to be fully operative will depend most on commitment of various schools to embrace E-learning in their various programs.

\section{Teaching of Languages through e-learning}

\section{The role of a computer connected to Internet.}

There has been much debate over the use of computers and the Internet in Foreign Language Teaching over the past few years. The techniques offering the activities and the degree of 
application in the language teaching syllabus have undergone a number of serious changes alongside the evolution of technology.

There was a time where computers assumed only the role of spelling and grammar checking. The methodology of language learning has developed a new way of using ICT in teaching, the Hypermedia. Hypermedia provides the language teacher and the language learner with multimedia resources, such as texts, graphics, sound, animation and video linked together. It offers an authentic learning environment, it combines listening with seeing. Skills can easily be integrated in the teaching/learning process; reading, writing, speaking, listening can be combined in task- based learning.

It is also better for learners to use Hypermedia in classes. They have greater control over their learning because they can go at their own pace, they can do some activities on their own, can skip some parts of the text or revise the ones they find difficult. Another major advantage of hypermedia usage is that the learner can focus on the content and access different links with grammar explanations, exercises, vocabulary and pronunciation.

But, above all, hypermedia brings variety to the class. Students get used to learning the foreign language in a new and pleasant way, not just by interacting with the teacher and reading from the book. The application of ICT gives more opportunities for communication between peer learners: they can exchange information in real time, they can participate in blog discussions, work in teams on different projects, exchange emails and search for information. By using the authentic material provided by the Internet, students will have a better insight into the culture of the country and people whose language they study (Padurean and Margan, 2009).

The Internet also offers a wide variety of reference materials like online dictionaries, encyclopedias and search machines which are very helpful for developing students' individual work. Students can find, while working alone, the missing information, the meaning of new words, synonyms, antonyms or can communicate with the rest of the group online, via e-mail or in any other ICT environment. In a language classroom the computer may have the following roles:

- Teacher: it teaches students new language;

- Tester: it tests students on the already learned structures;

- Tool: it assists students to do certain tasks;

- Data source: it provides students with the information they need to solve different tasks;

- Communication facilitator: it allows students to communicate with others. 


\section{Computer as a teacher}

Computerized teaching (computer as a teacher) uses multimedia CD ROMS. In such programmes, students can listen to recordings, watch videos, speak into the microphone, record their progress or learn words by clicking on pictures and hearing their pronunciation. An alternative to CD ROMS is the World Wide Web. Students can practice all their skills there and it is more useful for the teacher than the CD ROM because teachers can intervene with their own ideas or materials (Padurean and Margan, 2009).

\section{Computer as a tester}

Students can practice their knowledge of a specific language using different Internet websites. Unfortunately, programmes for practice are very limited in terms of practice materials. Basically, the practice material refers to multiple - choice exercises, dual - choice exercises, true or false. The only answer the computer can give is Right or Wrong.

Despite these limitations computer grammar or vocabulary practice is enjoyed by students because the latter feel like playing and get the feedback without fearing the teacher's criticism. They can also work in groups, sitting at the same computer and discussing the answers.

\section{Computer as a tool and data source}

Computers are seen as tools because they provide tools for acquiring a foreign language. The large number of web-sites, pictures, projects, exercises, audio and video materials represents tools in the teaching and learning process.

We all know that, due to computers and the Internet, we can access almost any information we need. A particular aspect to highlight is Random Internet navigation. It refers to students surfing the web with no particular aim. That is why teachers should offer learners a number of useful websites and guide them in such a way as to find out information as soon as possible and solve their tasks.

\section{Computer as communication facilitator}

Nowadays the Internet is the principal medium by which students can communicate with others. This can be done by e-mail, by chatting, or by participating in discussion forums. Teachers can set up discussion forums and use them to communicate with their students. Or students can exchange didactic e-mails, discussing a topic presented in the classroom or any other topic of interest (Padurean and Margan, 2009). 


\section{The advantages of ICT usage in Foreign Language Teaching can be grouped as: Capacity to control presentation}

This capacity marks the difference between computers and books. Books have a fixed presentation, unlike computers, which can combine visual with listening materials, text with graphics and pictures.

\section{Novelty and creativity}

A lecturer can use different materials for each lesson, not like in teaching with textbooks, where all classes presenting a certain topic are the same.

\section{Feedback}

Computers provide a fast feedback to students` answers through error correction. It not only spots the mistake but also corrects it, sometimes even giving the appropriate advice.

\section{Adaptability}

Computer programmes can be adapted by teachers to suit their students` needs and level of language knowledge. Unlike books, which are produced in a single uniform format and need to be taught irrespectively of students` problems, computer programmes are more learner- friendly (P a d u re a n and Mar g a n, 2009).

\section{Benefits of e-learning}

\section{Motivation}

Generally speaking, the use of technology inside or outside the classroom tends to make the class more interesting. However, certain design issues affect just how interesting the particular tool creates motivation. One way a program or activity can promote motivation in students is by personalizing information, for example by integrating the student's name or familiar contexts as part of the program or task. Others include having animate objects on the screen, providing practice activities that incorporate challenges and curiosity and providing a context (real-world or fantasy) that is not directly language-oriented. One quantifiable benefit to increased motivation is that students tend to spend more time on tasks when on the computer. More time is frequently cited as a factor in achievement.

\section{Adapting learning to the student}

Computers can give a new role to teaching materials. Without computers, students cannot really influence the linear progression of the class content but computers can adapt to the student. 
Adapting to the student usually means that the student controls the pace of the learning but also means that students can make choices in what and how to learn, skipping unnecessary items or doing remedial work on difficult concepts. Such control makes students feel more competent in their learning. Students tend to prefer exercises where they have control over content, such as branching stories, adventures, puzzles or logic problems. With these, the computer has the role of providing attractive context for the use of language rather than directly providing the language the student needs.

\section{Authenticity}

"Authenticity" in language learning means the opportunity to interact in one or more of the four skills (reading, writing, listening and speaking) by using or producing texts meant for an audience in the target language, not the classroom. With real communication acts, rather than teacher-contrived ones, students feel empowered and less afraid to contact others. Students believe they learn faster and better with computer-mediated communication. In networked computer environments, students have a conscious feeling of being members of a real community. In situations where all are learners of a foreign language, there is also a feeling of equality. In these situations students feel less stressed and more confident in a language learning situation, in part because surface errors do not matter so much.

\section{Critical thinking skills}

Use of computer technology in classrooms is generally reported to improve self-concept and mastery of basic skills, more student-centered learning and engagement in the learning process, more active processing resulting in higher-order thinking skills and better recall, gain confidence in directing their own learning. This is true for both language and non-language classrooms.

\section{Requirements for students and lecturers}

\section{Lecturers}

Instead of handing down knowledge to students and being the center of students' attention, teachers become guides as they construct the activities students are to do and help them as they complete the assigned tasks. In other words, instead of being directly involved in students' construction of the language, the teacher interacts with students primarily to facilitate difficulties 
in using the target language (grammar and vocabulary) that arise when interacting with the computer and/or other people.

Elimination of a strong teacher presence has been shown to lead to larger quantity and better quality of communication such as more fluidity, more use of complex sentences and more sharing of students' personal selves. However, teacher presence is still very important to students when doing Computer-assisted language learning (CALL) activities. Teachers should be familiar enough with the resources to be used to anticipate technical problems and limitations. Students need the reassuring and motivating presence of a teacher in Computerassisted language learning (CALL) environments. Most students report preferring to work in a laboratory with the teacher's or the tutor's presence rather than be completely on their own. The students too are able to enjoy various opportunities which were not enjoyed before the invention of the computer; there are opportunities for slow learners to still learn what is not clear to them in the school lesson if the computer based system is applied. Therefore it can be argued that the lecturer's task is: to prepare the class carefully, to know the stages of the lesson and its exact timing, to design activities for each stage, to be able to guide the students while working with the Internet, to have extra activities prepared in case something goes wrong and to ask for students` e-mail addresses in advance (P a d u r e a n and Ma r g a n, 2009).

\section{Students}

Students, too, need to adjust their expectations and their participation in the class in order to use Computer-assisted language learning (CALL) effectively. Rather than passively absorbing information, learners must negotiate meaning and assimilate new information through interaction and collaboration with someone other than the teacher, be it a classmate or someone from outside of the classroom. Learners must also learn to interpret new information and experiences on their own terms. However, because the use of technology redistributes teachers' and classmates' attention, less-able students can become more active participants in the class because class interaction is not limited to that directed by the teacher. Moreover more shy students can feel free in their own students'-centered environment. This will raise their selfesteem and their knowledge will be improving. If students are performing collaborative project they will do their best to finish within the set time limits.

E-learning program is time consuming not only for learners but for lecturers who must spend the double of time to prepare a course or to read comments, questions ... sent to him or her by 
learners. That doesn't mean that the lecturer must respond immediately to these queries/comments. Lecturers plan on how to be responding to these comments, maybe twice a week. Doing research in advance to give direction on what to look for on web is mandatory for lecturers. Thus they must be ready to spend more time on the web unlike in traditional teaching.

This program may reduce cases of exams irregularities. Candidates sitting exams may do so in different centres spread across the country or any other centre recognized by university. There will be no longer crowded exams rooms. It will be easy for invigilator to control candidates and dissuade them from using irregular materials during exams. Exams may be available on platform with the possibility of setting time to accessing it and to close it. Those tests must also promote creativity of the candidate rather than reproducing what was given by lecturers. 


\section{Conclusion}

The benefits of the use of ICT in Modern Foreign Languages are evident. They include the increase in students' motivation, enthusiasm and confidence; Positive association with attainment; learning possibilities expanded via collaboration, interaction and communication in the target language; potential for differentiation according to individual student need. Lecturers can maximize the impact of ICT in teaching of foreign languages by: maximizing access to ICT resources, using the advantages of multimedia to engage learners' interest and develop their key skills and using ICT to interact with native speakers and authentic materials. Widened use of ICTs for e-learning in Moi University's Schools will improve the quality of teaching, learning and management and help raise the standards of education in the country. It will go a long way in enhancing access, quality, relevance and equity of education. Embracing e-learning practices will steer Moi University towards joining the rest of the world in instituting positive technological innovations in the education sector. 


\section{References}

Arnold, T., Cayley, S., and Griffith, M., Video Conferencing in the Classroom: Communications Technology across the Curriculum. Becta. http://www.becta.org.uk/, 2002

Blyth, A., E-mail communication between year 9 students in an English and a German school. Technology integrated pedagogical strategies (TIPS) website case reports. http://www.educ.cam.ac.uk/, 2001

Butler, J, C., "Is the Internet helping to create learning environments?" Campus-Wide Information Systems, 17(2000) (2), ISSN 1065-0741

Commonwealth of Learning, An Introduction to Open and Distance Learning, www.col.org/introODL.htm, 2000

Davidson-Shivers, G. V., and Rasmussen K.L., Web Based Learning: Design, Implementation and Evaluation, Pearson Education, Inc. Upper Saddle River, New Jersey, 2006

Davies G. "Lessons from the past, lessons for the future: 20 years of CALL". In Korsvold A-K. \& Rüschoff B. (eds.) New technologies in language learning and teaching, Strasbourg: Council of Europe. http://www.camsoftpartners.co.uk/coegdd1.htm, 1997

Davies, G., Bangs, P., Frisby, R., \& Walton E., Setting up effective digital language laboratories and multimedia ICT suites for MFL, CILT, The National Centre for Languages and the Association for Language Learning, www.languages-ict.org.uk, 2005

Davies, G., 'ICT and Modern Foreign Languages: Learning Opportunities and Training Needs', International Journal of English Studies, vol. 2 (2002) no.1 pp1-18

DODL, Open and Distance Learning Manual: E-Learning Xhtml Editor Exe, Moi University Press, Moi University, Eldoret, 2007

DODL, Annual Report: November 2007- December 2008, Moi University Press, Moi University, Eldoret, 2008

DODL, Presentations-Schools, Moi University Press, Moi University, Eldoret, 2008 
DODL, Kisumu and Naivasha Reports: A Report of the VLIR-OUS ICT Project Workshop on E-Content Development for Trainers of Trainers (ToT) Held at the Kenya Wildlife Service Training Institute, Naivasha Between $23^{\text {rd }}$ and $28^{\text {th }}$ March, 2009, Moi University Press, Moi University, Eldoret, 2009

Eastment, D. The Internet and ELT. The British Council, 1999

Ely P. Bring the lab back to life, Oxford: Pergamon, 1984

Government of Kenya, Economic Survey, Government Printers, Nairobi, 2010

Harris, S., And Kington, A., Innovative classroom practices using ICT in England. NFER. http://www.nfer.ac.uk/research/downloads/, 2002

Harmer, J., The Practice of English Language Teaching. Longman, 2005

Harrison, C., et al., ImpaCT2: The impact of information and communication technologies on pupil attainment. ICT in Schools Research and Evaluation Series, No. 7. DfES/Becta. http://www.becta.org.uk/page documents/, 2002

Hill B. Video in language learning, London: CILT, 1999

Holmberg, B., Theory and Practice of Distance Education, Routledge, London, 1989

International Certificate Conference, The Impact of Information and Communications Technologies on the Teaching of Foreign Languages and on the Role of Teachers of Foreign Languages http://www.icc-europe.com/ICT in FLT Final ,2003

Integrating ICT into Language Learning and Teaching, Guide for Authors - available at www.elearningguides.net /.../3b-GUIDES-TUTORS-EN.pdf

Juwah, C., Interactions in Online Education: Implications for Theory and Practice, Routledge, Taylor and Francis Group, London and New York, 2006

Kelsey, K. D. Preparing Online Instructors: An Introduction to Open and Distance Learning, Oklahoma State University Press, Oklahoma State University, 2009 
Menon, M, G, K, "Transformative Synthesis of Education and Information Technology", Address at the $12^{\text {th }}$ convocation of IGNOU held at New Delhi on 3rd March 2001 University News, 39 (27), 2-8 July (2001), pp 13-17

Moore, M. G., and Kearsley, Distance Education: A Systems View, Wadsworth Publishing Company, New York, 1996

Oosterhof, A., Conrad, R., and Ely D.P., Assessing Learners Online, Pearson Education, Inc. Upper Saddle River, New Jersey, 2008

$\mathrm{P}$ a d u r e a n, A., and Ma r g a n, M., Foreign Language Teaching via ICT Revista de Informatica Sociala vol. VII nr. 12 / Decembrie 2009 ISSN 1584-384X,

Passey, D., Rogers, C., Machell, J., and McHugh, G. The Motivational Effect of ICT on Pupils. Report No: RR523. DfES. http://www.dfes.gov.uk/research/data/, 2004

Provenzo, E.F., The Internet and Online Research for Teachers ( $3^{\text {rd }}$ ed.), Pearson Education, Inc. New York, 2005

Rumajogee, A. R., Distance Education and Open Learning in Sub-Saharan Africa: A Literature Survey on Policy and Practice, Association for the Development of Education in Africa Press, Association for the Development of Education in Africa, 2002

Salmon, G., e-tivities: The Key to Active Online Learning, Routledge Falmer, Taylor and Francis Group, London and New York, 2002

Skehan, P. English Language Learning. London. University of London, 1999

Sperling, D. Dave Sperling’s Internet Guide. New Jersey. Prentice Hall, 1998

Teachernet, undated. Case Study: ICT supporting early language teaching. Teachernet. http://www.teachernet.gov.uk/CaseStudies/

The Standard, "Transforming education through e-learning " : The $1^{\text {st }}$ Regional e-learning Conference, Kenya Institute of Education, March $29^{\text {th }}$ to $31^{\text {st }} 2010$, Nairobi.

\section{$\underline{\text { Acronyms }}$}


CALL Computer Assisted Language Learning, the term that is favored worldwide to refer to the use of ICT in language learning and teaching in its broadest sense

CE Conventional Education

DODL Directorate of Open and Distance Learning

GoK Government of Kenya

ICT Information and Communication Technology

This tends to be the preferred term, replacing IT (Information Technology), because it shows the importance of electronic communications such as email, the Web and videoconferencing, as well as the computer aspect.

INWENT Internationale Weiterbildung und Entwicklung gGmbH

KIE: $\quad$ Kenya Institute of Education

LAN Local Area Network

MFL Modern Foreign Languages

This is the preferred term in the UK, especially when referring to the National Curriculum, though elsewhere FL (Foreign Languages) is more common.

MU Moi University

ODL Open and Distance Learning

WAN Wide Area Network. 